\title{
Author Correction to: Denosumab: A Review in Postmenopausal Osteoporosis
}

\author{
Emma D. Deeks ${ }^{1}$
}

Published online: 9 March 2018

(C) Springer International Publishing AG, part of Springer Nature 2018

\section{Author Correction to:}

Drugs Aging (2018) 35:163-173

https://doi.org/10.1007/s40266-018-0525-7

\section{Correction in reviewer name}

In the original publication the name of the fourth reviewer was incorrectly published.

In Page 1: reviewer listing, the name of the fourth reviewer, which

Previously read:

"Y-V. Reginster".

Should read:

"J-Y. Reginster".

The original article can be found online at https://doi.org/10.1007/ s40266-018-0525-7.

\footnotetext{
Emma D. Deeks

demail@springer.com

1 Springer, Private Bag 65901, Mairangi Bay, Auckland 0754,

New Zealand
} 